\title{
Clinical Characteristics of Patients who Died Within a Year in a Tertiary Intensive Care Unit
}

\section{Üçüncü Basamak Bir Yoğun Bakım Ünitesinde Bir Yıl ıçinde Ölen Hastaların Klinik Özellikleri}

\author{
๑Ökkeş Hakan Miniksar1 ${ }^{1}$ EErol TOY² \\ 'Yozgat Bozok University, Faculty of Medicine, Department of Anesthesiology and Reanimation, Yozgat, Turkey \\ ${ }^{2}$ Karabuk University Training and Research Hospital, Deparment of Anesthesiology, Karabük, Turkey \\ Copyright@Author(s) - Available online at www.dergipark.org.tr/tr/pub/medr \\ Content of this journal is licensed under a Creative Commons Attribution-NonCommercial 4.0 International License.
}

\begin{abstract}
Aim: The aim of this study was to find out the clinical characteristics of patients who died within a year in the intensive care unit (ICU) and to find out the association of ICU admission albumin, lactate levels and Acute Physiology and Chronic Health Evaluation II (APACHE II) scores of these patients who died with ICU length of stay.

Material and Method: The files of patients who died in the ICU (n:350) between January 2018 and December 2018 were examined retrospectively. The patients' demographic data and their clinical characteristics, ICU admission types (surgery or medical medicine), the units they were admitted in, reasons for admission, comorbidities, admission albumin and lactate levels, APACHE II scores and ICU length of stay were recorded. The association of patients' clinical characteristics with ICU length of stay and laboratory values was evaluated.

Result: The patients' mean age was $72.68 \pm 12.98$ years, mean APACHE II score was $27.0 \pm 10.0$, mean albumin value was $3.1 \pm 0.7 \mathrm{~g} / \mathrm{dL}$ and mean lactate value was $4.1 \pm 3.3 \mathrm{mmol} / \mathrm{L}$. It was found that albumin value was lower in patients admitted to ICU with mechanical ventilator $(\mathrm{MV})$ need $(\mathrm{p}<0.001)$, and lactate value and APACHE II score were significantly higher in patients with post-cardiopulmonary resuscitation $(p<0.001)$. Mean ICU length of stay was $28.24 \pm 37.53$ days. A weak positive correlation $(r=0.172, p=0.001)$ was found between the patients' length of stay and albumin, and a weak negative correlation was found with the lactat $(r=0.121, p=0.023)$ and APACHE II scores $(r=0.151, p=0.001)$. A weak negative correlation was found between the patients' albumin and lactate $(r=0.152$, $p=0.004)$, and APACHE II score $(r=0.179, p=0.001)$, as well as a moderate positive correlation between lactate and APACHE II score. Conclusion: Significant association was found between hypoalbuminemia, hyperlactatemia and high APACHE II scores and ICU length of stay in patients who died in ICU. More comprehensive studies are needed to show the effects of this association on effective use of ICUs.
\end{abstract}

Keywords: Intensive care; mortality; length of stay; hypoalbuminemia; hyperlactatemia

Öz

Amaç: Amaç: Bu çalışmada Yoğun Bakım Ünitesinde (YBÜ) bir yıl içinde mortalite gözlenen hastaların klinik özelliklerinin saptanması ve YBÜ'ye kabul esnasında albümin, laktat seviyelerinin ve Acute Physiology and Chronic Health Evaluation II (APACHE II) skorlarının YBÜ yatış süresi ile ilişkisinin belirlenmesi amaçlandı.

Materyal ve Metot: Çalışmada Ocak 2018 ve Aralık 2018 tarihleri arasında YBÜ'de mortalite gözlenen (n:350) hastaların dosyaları retrospektif olarak incelendi. Hastaların demografık verileriyle birlikte klinik özellikleri, YBÜ'ye kabul tipi (cerrahi veya dahili), kabul edildiği üniteleri, kabul nedenleri, komorbiditeleri, kabul albümin ve laktat seviyeleri, APACHE II skorları ve YBÜ yatış süreleri kayıt edildi. Hastaların klinik özelliklerinin YBÜ yatış süresi ve laboratuvar değerleri ile ilişkisi değerlendirildi.

Bulgular. Hastaların yaş ortalaması $72.68 \pm 12.98$ yıl, ortalama APACHE II skoru 27.0 \pm 10.0 , albümin değeri $3.1 \pm 0.7 \mathrm{~g} / \mathrm{dL}$ ve laktat değeri $4.1 \pm 3.3 \mathrm{mmol} / \mathrm{L}$ olarak belirlendi. Mekanik ventilatör (MV) ihtiyacı nedeniyle YBÜ'ye kabul edilen hastalarda albümin değerinin daha düşük olduğu $(p<0.001)$, laktat değerinin ve APACHE II skorunun post-kardiyopulmoner resusitasyon hastalarda anlamlı olarak daha yüksek olduğu saptandı $(p<0.001)$. YBÜ yatış süresi ortalaması $28.24 \pm 37.53$ gündü. Hastaların yatış süresi ile albümin arasında zayıf pozitif korelasyon $(r=0.172, p=0.001)$, laktat $(r=0.121, p=0.023)$ ve APACHE II skorları ile zayıf negatif korelasyon bulundu $(r=0,151$, $p=0,001)$. Hastaların albümin ile laktat $(r=0.152, p=0.004)$ arasında ve APACHE II skoru $(r=0.179, p=0.001)$ arasında zayıf negatif korelasyon ve laktat ile APACHE II skoru arasında $(r=0,401, p<0.001)$ orta derecede pozitif korelasyon bulundu.

Sonuç: Bu çalışmada, YBÜ'de mortalite gözlenen hastalarda hipoalbuminemi, hiperlaktatemi ve yüksek APACHE II skorları ile YBÜ yatış süresi arasında anlamlı bir ilişki gözlendi. Bu ilişkinin YBÜ'lerin etkin kullanımına etkilerini göstermek için daha kapsamlı araştırmalar gereklidir.

Anahtar Kelimeler : Yoğun bakım; mortalite; yatış süresi; hipoalbuminemi; hiperlaktatemi 


\section{INTRODUCTION}

Intensive care units (ICU) are special units where critical patients are followed up closely and treated and their life functions are supported by advanced technological devices (1). Due to the increase in elderly population with comorbidities in the world and in our country, the need for ICUs has been increasing.

Management and performance assessment of ICUs can be affected by a large number of factors such as care process and organization (2). Unlike other departments of hospitals, ICUs are the units with the highest rate of mortality due to critical patients (3). Mortality rates in ICU vary depending on factors such as the underlying comorbidities of the patients, hospitalization indicators, advanced age, interventional procedures applied, the structure of ICUs and length of stay (LOS) $(3,4)$. In European countries, ICU mortality rate is reported as between $6.7 \%$ and $17.8 \%$ (4), while it is reported as between $8 \%$ and $19 \%$ in USA (5). In our country, altough it varies according to most centers, ICU mortality rate is reported as between $3 \%$ and $51 \%$ (69). Although the current ICU bed capacity is sufficient in our country when compared with other countries, there are problems in the effective use of ICUs (10). Therefore, it is necessary to predetermine the patients who cannot make use of treatment in ICU, to know the factors that increase mortality rates and to provide an effective critical care triage. ICUs are becoming units where chronic patients who do not benefit from acute period treatment and whose LOS is prolonged due to advanced technological support therapies are hospitalized (11). Long LOS in ICU is associated with high mortality rate and negative complications (1). In addition, long LOS in ICUs may cause critical patients who may benefit from ICU not to receive healthcare services (12). On the other hand, finding out the clinical characteristics of critical patients who die and the factors related with length of stay is important for effective use of limited number of ICU beds during the current COVID-19 pandemic.

The primary objective of this study is to describe the clinical characteristics of patients who died within a year in the general intensive care unit of a regional tertiary hospital. The secondary objective of the study is to find out the association of ICU admission albumin, lactate levels and Acute Physiology and Chronic Health Evaluation II (APACHE II) scores of these patients who died with clinical parameters and ICU length of stay.

\section{MATERIAL AND METHOD}

\section{Ethics Statement}

Ethics committee approval of this study was taken from local Clinical Researches Ethics Committee in accordance with the Declaration of Helsinki (date: Jul 24, 2019; Approval No:134).

\section{Design and Setting of the Study}

This study was conducted by retrospectively examining the data of 350 (33.3\%) of 1050 patients who were treated in ICU of a tertiary hospital between January 2018 and December 2018 and who met the inclusion criterion $(>18$ years of age). The IUC of this hospital is a closed system with 36 beds and provides advanced treatment service to all adult medical medicine and surgery critical patients.

\section{Study Data}

The data were obtained from patient files and hospital information system automation program. Patients' demographic data and their ICU admission type (surgery or medical medicine), units they were admitted in, reasons for admission, their comorbidities and length of stay were evaluated. APACHE II scores of all patients calculated on admission to ICU, their admission albumin and lactate values were recorded. The patients' reasons for admission to ICU were classified according to ICD-10 (International Classification of Diseases) codes. The patients who underwent resuscitation after cardiac or respiratory arrest were grouped as post-CPR (post-Cardiopulmonary Resuscitation). All patients were routinely consulted for medical departments (cardiology, respiratory disease or medical medicine) in the preoperative period. The presence of comorbidities in the patients was confirmed by examining the consultation records obtained during the patients' stay in ICU. The comorbidity status was divided into two categories: "Two or less comorbidities", "Three or more comorbidities". Those with Alzheimer's or Parkinson's disease as comorbidity were included in the neurodegenerative disease group. APACHE II scores were divided into two categories according to the median (27) value: "APACHE below 27 score", "APACHE above 27 score". The age group was divided into two categories as under 65 and above. The association of clinical variables with albumin, lactate levels, APACHE II score and length of stay in the ICU was examined.

\section{Statistical analysis}

All statistical analyses were performed using SPSS v.20.0 (IBM Corp., Armonk, NY, USA) software. Frequency, mean, standard deviation, percentage (\%), median, and interquartile range (25-75 $p$ ) values were determined with the analysis of the data. Normality was assessed using the Kolmogorov-Smirnov test. The statistical difference between the two groups was evaluated using the MannWhitney $U$ test and student $t$ test and the Chi-Square test. Kruskal-Wallis test were used for analysis between groups at each time point for nonparametric continuous and ordinal data. Correlations between albumin, lactate level, APACHE scores, and length of stay were analyzed using the Spearman's correlation test for non-normally distributed variables and the Pearson distribution for normally distributed variables.

\section{RESULT}

\section{Demographic and clinical characteristics of the patients}

$164(46.9 \%)$ of the patients were male, while 186 $(53.1 \%)$ were female and mean age was found as $72.68 \pm 12.98(\min =19, \max =96)$ years. $273(78 \%)$ of the 
patients were aged 65 and older. Hypertension (46.6\%), neurodegenerative disease $(31.1 \%)$ and respiratory disease (30.6\%) were the most common comorbidities.

\section{The association of clinical characteristics with albumin, lactate levels and APACHE II score}

It was found that mean ICU admission APACHE II score of the patients was $27.0 \pm 10.0$, while their mean albumin value was $3.1 \pm 0.7 \mathrm{~g} / \mathrm{dL}$ and mean lactate value was $4.1 \pm 3.3 \mathrm{mmol} / \mathrm{L}$. It was found that the patients were most frequently admitted to the ICU from emergency service (64\%). It was found that serum albumin $(p=0.078)$ and lactate $(p=0.256)$ levels of patients did not differ significantly in terms of the units patients were admitted to, while their APACHE II scores differed significantly and the highest APACHE II score was found in patients who were transferred from medical ICU. It was found that while $294(84 \%)$ of the patients were admitted to ICU for medical causes, $56(16 \%)$ were admitted for surgical causes. No significant differences were found in albumin and lactate values of the patients in terms of their ICU admission types and APACHE II score was significantly higher in medical patients $(p=0.002)$. When ICU admission diagnoses were examined, it was found that albumin value was significantly lower in patients who needed MV $(p<0.001)$, while lactate value and APACHE II score were significantly higher in post-CPR patients $(p<0.001)$. Albumin values were found to be lower in the patient group aged 65 and older $(p=0.002)$. In patients with APACHE II score above 27 , it was found that albumin values were significantly lower $(p=0.011)$ and lactate values were higher $(p<0.001)$ (Table 1).

Table 1. The association of study variables with albumin, lactat levels and APACHE score

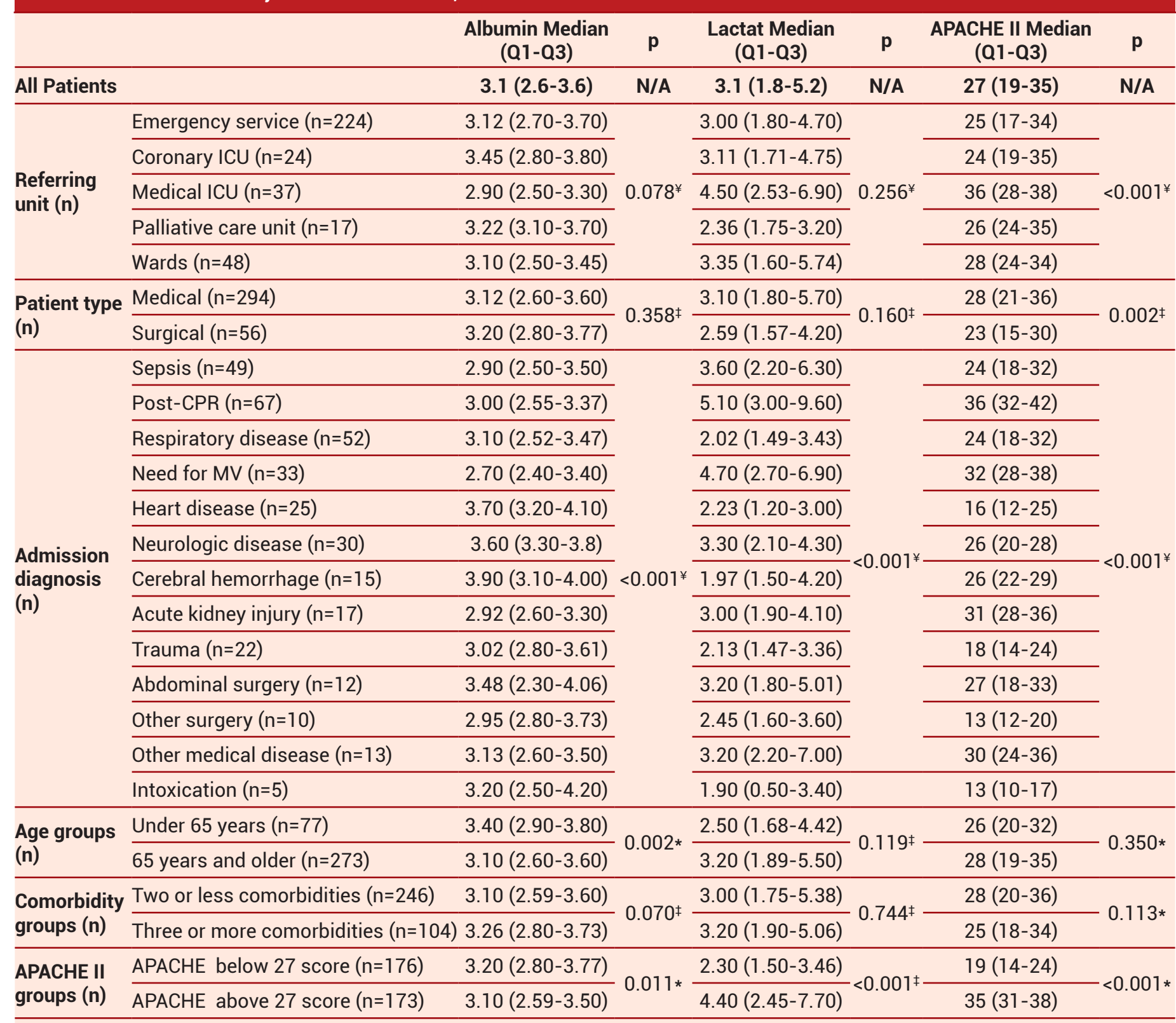

Significant $p$ values are written in bold.

${ }^{¥}$ Kruskal-Wallis test ; *Mann-Whitney U test; †independent samples t-test 
Table 2. The association of LOS with study variables

\begin{tabular}{|c|c|c|c|c|c|}
\hline & & \multirow[b]{2}{*}{ Median } & \multicolumn{2}{|c|}{ Length of ICU stay } & \multirow{2}{*}{$p$ value } \\
\hline & & & Percentile 25 & Percentile 75 & \\
\hline \multicolumn{6}{|l|}{ All Patients } \\
\hline \multirow{2}{*}{ Gender } & Male $(n=164)$ & 14 & 3 & 55 & \multirow{2}{*}{$0.207^{\ddagger}$} \\
\hline & Female $(n=186)$ & 7 & 3 & 39 & \\
\hline \multirow{5}{*}{ Referring unit } & Emergency service $(n=224)$ & 8 & 3 & 38 & \multirow{5}{*}{$0.509^{*}$} \\
\hline & Coronary ICU $(n=24)$ & 10 & 3 & 52 & \\
\hline & Medical ICU (n=37) & 25 & 3 & 45 & \\
\hline & Palliative care unit $(n=17)$ & 29 & 4 & 63 & \\
\hline & Wards $(n=48)$ & 11 & 4 & 50 & \\
\hline \multirow{2}{*}{ Patient type } & Medical $(n=294)$ & 12 & 3 & 48 & \multirow{2}{*}{$0.115 *$} \\
\hline & Surgical $(n=56)$ & 6 & 3 & 10 & \\
\hline \multirow{13}{*}{ Admission diagnosis } & Sepsis $(n=49)$ & 6 & 3 & 24 & \multirow{13}{*}{$<0.001^{\ddagger}$} \\
\hline & Post-CPR (n=67) & 8 & 2 & 46 & \\
\hline & Respiratory disease $(n=52)$ & 30 & 7 & 56 & \\
\hline & Need for MV $(n=33)$ & 4 & 3 & 12 & \\
\hline & Heart disease $(n=25)$ & 52 & 46 & 63 & \\
\hline & Neurologic disease $(n=30)$ & 14 & 5 & 56 & \\
\hline & Cerebral hemorrhage $(n=15)$ & 8 & 5 & 35 & \\
\hline & Acute kidney injury $(n=17)$ & 13 & 5 & 38 & \\
\hline & Trauma $(n=22)$ & 6 & 4 & 9 & \\
\hline & Abdominal surgery $(n=12)$ & 5 & 3 & 13 & \\
\hline & Other surgery $(n=10)$ & 5 & 3 & 8 & \\
\hline & Other medical disease $(n=13)$ & 35 & 4 & 62 & \\
\hline & Intoxication $(n=5)$ & 3 & 3 & 7 & \\
\hline \multirow{2}{*}{ Age groups } & Under 65 years $(n=77)$ & 46 & 31 & 62 & \multirow{2}{*}{$<0.001^{\ddagger}$} \\
\hline & 65 years and older $(n=273)$ & 6 & 3 & 25 & \\
\hline \multirow[b]{2}{*}{ Comorbidity groups } & Two or less comorbidities $(n=246)$ & 13 & 5 & 58 & \multirow[b]{2}{*}{$0.161^{\ddagger}$} \\
\hline & $\begin{array}{l}\begin{array}{l}\text { Three or more comorbidities } \\
(n=104)\end{array} \\
\end{array}$ & 8 & 3 & 39 & \\
\hline
\end{tabular}

Significant $\mathrm{p}$ values are written in bold.

$¥$ ¥ruskal-Wallis test ; *Mann-Whitney U test; łindependent samples t-test.

\section{The association of LOS with study variables}

The mean of LOS in the intensive care unit was $28.24 \pm$ $37.53(\min =1, \max =275)$ days. Among clinical factors admission diagnosis $(p<0.001)$ and age groups $(p<0.001)$ affected LOS. Those with heart disease had the highest LOS (52 days). It was determined that patients aged 65 and over had shorter LOS (6 days). The distribution of LOS based on clinical and nonclinical variables is demonstrated in Table 2.

The association between ICU length of stay and albumin, lactate and APACHE score

A weak positive correlation $(r=0,172, p=0,001)$ was found between the patients' LOS and albumin, and a weak negative correlation was found with the lactat $(r=0,121$, $p=0,023)$ and APACHE scores $(r=0,151, p=0,001)$. A weak negative correlation was found between the patients' albumin and lactate $(r=0,152, p=0,004)$, and APACHE II score $(r=0,179, p=0,001)$, as well as a moderate positive correlation between lactate and APACHE II score ( $r$ $=0,401, p<0.001)$ (Table 3) (Figure 1).

\begin{tabular}{|c|c|c|c|c|}
\hline & & LOS & Albumin & Lactat \\
\hline \multirow{2}{*}{ Albumin } & $r$ & 0.172 & & \\
\hline & $p$ & 0.001 & & \\
\hline \multirow{2}{*}{ Lactat } & $r$ & -0.121 & -0.152 & \\
\hline & $p$ & 0.023 & 0.004 & \\
\hline \multirow{2}{*}{ APACHE II score } & $r$ & -0.151 & -0.179 & 0.401 \\
\hline & $p$ & 0.005 & 0.001 & $<0.001$ \\
\hline
\end{tabular}




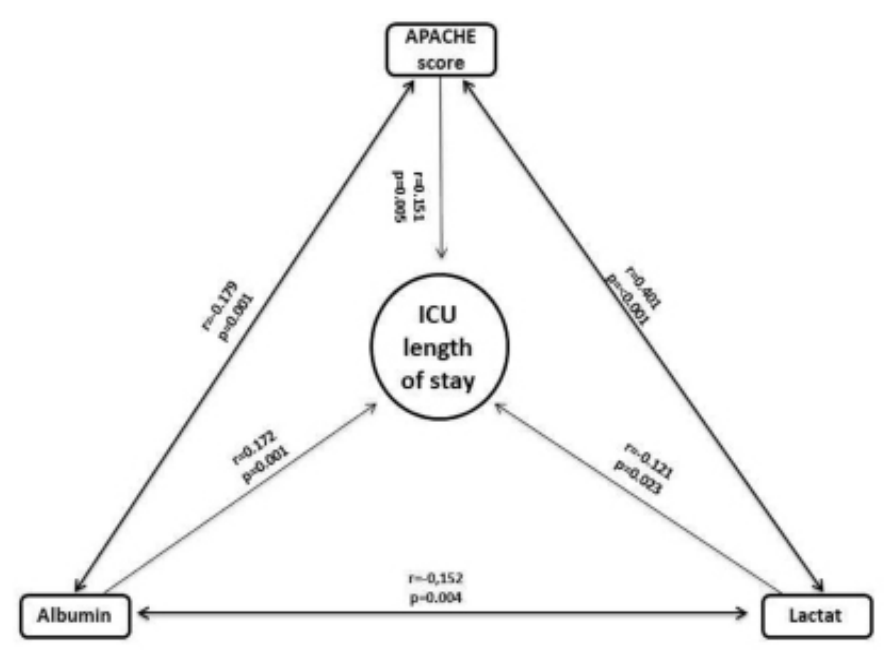

Figure 1. Relationship between length of stay in ICU, albumin, lactate and APACHE II score

\section{DISCUSSION}

ICUs are units where critical patients with high mortality rates are followed. When the literature is reviewed, it can be seen that while ICU mortality rates differ by centres, they vary between $23 \%$ and $51 \%(6-9)$. In this study, one-year mortality rate in ICU was found as $33.3 \%$, in line with the literature. A great majority of these critical patients in ICU consist of elderly patients with chronic health problems and multiple organ failures $(2,13,14)$. In this study, mean age of the patients who died was found as $72.68 \pm 12.98$ years and $78 \%$ were in geriatric age $(>65)$ group. Although age is an important prognostic factor in critical patients in ICU (13); severity of the disease, reasons for admission to ICU and presence of comorbidities have been determined as risk factors more important than age in other studies $(2,13,14)$.

A large number of studies have shown that hypoalbuminemia, hyperlactatemia and high APACHE II scores contribute to high mortality rates in critical patients in ICU $(15,16)$. The relationship between these variables and mortality and LOS was examined in detail in this study. When the literature is reviewed, it can be seen that the significance of hypoalbuminemia in predicting increased mortality, increased MV time and increased ICU length of stay has been emphasized (15). In this study, mean ICU admission albumin level was found as $3.1 \mathrm{~g} / \mathrm{d} \mathrm{L}$ and hypoalbuminemia was found in geriatric patients with MV needs most frequently. Other than these, a positive significant relationship was found between albumin level and LOS.

Patients' reasons for admission to ICU are also effective on mortality and different reasons have been put forward in a large number of studies in literature (14,17-20). Although primary hospitalization indications have been reported as cardiovascular diseases (14), respiratory failure (17), gastrointestinal diseases (18), sepsis and stroke, reasons for admission vary in terms of patient population and ICU type. In the present study, primary hospitalization indications were found as post-CPR and
MV need. In a large number of studies, it has been reported that MV need is increased in critical patients and this situation is associated with poor prognosis $(21,22)$. The presence of hyperlactatemia and high APACHE II levels in this patient group support this situation. It was found that $84 \%$ of the patients were admitted to ICU with medical medicine reasons and LOS of these patients was higher in these patients when compared with those who were admitted with surgical reasons, although not statistically significant. Similarly, in their study, Meregalli et al. (23) reported that LOS in ICU was higher in medical patients when compared with surgical patients. Majority of the patients were transferred from the emergency service. It was found that the albumin level was the lowest and lactate and APACHE II level were the highest in patients transferred from in-hospital medical ICU. We think that the reason for this may be the fact that most of the patients were critical patients who needed MV after resuscitation.

The presence of comorbidities also has a negative effect on ICU results $(13,14)$. In this study, almost all of the patients had at least one chronic disease and in line with the literature, the most common comorbidity was hypertension (46.6\%), neurodegenerative diseases $(31.1 \%)$ and respiratory diseases (30.6\%) (18,24). However, no significant difference was found in ICU length of stay and other variables in terms of comorbidity groups.

It has been reported that mortality is higher in patients with long LOS in ICU and life span is shortened with LOS (25). In this study, ICU LOS was found to be shorter in patients with MV need and in elderly group. We think that high mean age in our study contributed both to high mortality rate and shorter mean length of stay. In addition, the causes in LOS and mortality are multi-factorial and vary according to ICU characteristics (26).

Another important result of the study is the result that ICU LOS has a positive significant relationship with albumin level and a negative significant relationship with lactate level and APACHE II score. Blood lactate level is one of the parameters used in predicting the prognosis of ICU patients. Hyperlactatemia is usually a multi-factorial condition due to tissue hypoxia that develops as a result of respiratory and circulatory disorders (23). Adıyaman et al. found that both mortality and IC LOS were significantly longer in patients with $>2 \mathrm{mmol} / \mathrm{L}$ lactate (16). However, in our study it was found that lactate level had a negative association with IC LOS and positive association with APACHE II score. One of the ICU scoring systems used in predicting mortality is APACHE II, which is widely accepted around the world. It is evaluated in the first 24 hours of intensive care hospitalization and the values that deviate the most from the normal are taken (27). In our study, it was found that mean APACHE II score was high and had a negative association with IC LOS. In addition, albumin level was found to be low and lactate level was found to be high in the patient group with high APACHE score. Similarly, it was found in another study that serum 
lactate level was significantly correlated with APACHE scores and associated with LOS (28). Based on all these results, we can say that there is a significant association between ICU admission albumin, lactate levels and APACHE scores and LOS in critical patients.

\section{CONCLUSION}

In this study, it was found that most of the patients who died in ICU were elderly patients with comorbidities. A significant association was found between hypoalbuminemia, hyperlactatemia and high APACHE II scores and ICU length of stay in these patients. Based on our results, knowing the factors related to mortality and length of stay in ICU and taking the necessary precautions may contribute to effective use of ICUs.

Financial disclosures: The authors declare that this study has received no financial support.

Conflict of Interest: The authors have no conflicts of interest to declare

Ethical approval: Ethics committee approval of this study was taken from local Clinical Researches Ethics Committee in accordance with the Declaration of Helsinki (date: Jul 24, 2019; Approval No:134).

\section{REFERENCES}

1. MMartin $C M$, Hill $A D$, Burns $K$, et al. Characteristics and outcomes for critically ill patients with prolonged intensive care unit stays. Crit Care Med. 2005;33:1922-7.

2. Ihra GC, Lehberger $\mathrm{J}$, Hochrieser $\mathrm{H}$, et al. Development of demographics and outcome of very old critically ill patients admitted to intensive care units. Intensive Care Med. 2012;38:620-6.

3. Weigl W, Adamski J, Goryński P, et al. ICU mortality and variables associated with ICU survival in Poland: A nationwide database study. Eur J Anaesthesiol. 2018;35:949-54.

4. Weigl W, Adamski J, Goryński P, et al. Mortality rate is higher in Polish intensive care units than in other European countries. Intensive Care Medicine. 2017;43:1430-2.

5. Siddiqui S. Mortality profile across our Intensive Care Units: A 5-year database report from a Singapore restructured hospital. Indian J Crit Care Med. 2015;19:726-7.

6. Pehlivanlar Küçük $M$, Özlü $T$, Küçük $A O$, et al. Mortality prediction ability of phycians in intensive care units of Turkey. Tuberk Toraks 2020;68:205-217.

7. Evaluatıon of Mortalıty Rate and Risk Factors in Intensıve Care Unit. J Ankara Training Res Hospital. 2020;53:20-4.

8. Akkoc I, Yucetas E, Isıtemız I, et al. Mortality Rate In Intensive Care Units of Tertiary Health Institutions and Identifying Risk Factors: Analysis of 3945 Patients. Bezmialem Sci. 2017;5:116-20.

9. Cantürk M. Analysis of Patients Discharged as Exitus from Intensive Care Unit: One Year Data of a Tertiary Health Institution. Ahi Evran Medical J. 2018;3:34-40.

10. https://www.saglik.gov.tr/TR,62400/saglik-istatistikleriyilligi-2018. Health Statistics Yearbook 2018. Available from: March 2021.

11. Nelson JE, Cox CE, Hope AA, et al. Chronic critical illness. Am J Respir Crit Care Med. 2010;182:446-54.

12. Kıray G, Inal MT, Memiş D, et al. Investigation of the Factors Affecting Prolonged Intensive Care Unit. Turkish J Intensive Care. 202018:84-90.

13. Boumendil A, Somme D, Garrouste-Orgeas M, et al. Should elderly patients be admitted to the intensive care unit? Intensive Care Med. 2007;33:1252-62.

14. Bagshaw SM, Webb SAR, Delaney A, et al. Very old patients admitted to intensive care in Australia and New Zealand: A multi-centre cohort analysis. Crit Care. 2009;13:45.

15. Atalay E, Erdoğdu Hi, Tur BK, et al. The relationship between c reactive protein/albumin ratio and 1-year mortality in hospitalized elderly copd patients with acute exacerbation. Turk Geriatr Derg. 2019;22:9-17.

16. Adıyaman E, Tokur ME, Mermi Bal Z, et al. Retrospective Analysis of Trauma Patients Who were Treated and Followed in Anesthesia Intensive Care Unit. Turkish J Intensive Care. 2019;17:146-53.

17. Akın S, Gündoğan K, Coşkun R, et al. Critically III Elderly Patient Mortality: Is Age a Risk Factor? J Med Surg Intensive Care Med. 2014;5:26-9.

18. Becker S, Müller J, Heer G, et al. Clinical characteristics and outcome of very elderly patients $\geq 90$ years in intensive care: a retrospective observational study. Ann Intensive Care. 2015;5:1-8.

19. Al-Dorzi HM, Tamim HM, Mundekkadan S, et al. Characteristics, management and outcomes of critically ill patients who are 80 years and older: A retrospective comparative cohort study. BMC Anesthesiol. 2014;14:1-9.

20. Doğan Baki E, Yüksek A, Bezen BA, et al. Retrospective analysis of anesthesia in geriatric patients during endoscopic retrograde cholangiopancreatography abstract. Turk Geriatr. Derg 2018;21:225-30.

21. Rellos K, Falagas ME, Vardakas KZ, et al. Outcome of critically ill oldest-old patients (aged 90 and older) admitted to the intensive care unit. J Am Geriatr Soc. 2006;54:110-4.

22. Lai CC, Ko SC, Chen CM, et al. The outcomes and prognostic factors of the very elderly requiring prolonged mechanical ventilation in a single respiratory care center. Med (United States). 2016;95:1-5.

23. Meregalli A, Oliveira RP, Friedman G. Occult hypoperfusion is associated with increased mortality in hemodynamically stable, high-risk, surgical patients. Crit Care. 2004;8:60-5.

24. Demircan A, Aygencel Bikmaz G, Kadi G, et al. Evaluation of the general characteristics of patients aged 85 years and above admitted to a university hospital emergency department. Turkish J Med Sci. 2017;47:1393-402.

25. Laupland KB, Kirkpatrick AW, Kortbeek JB, Zet al. Long-term mortality outcome associated with prolonged admission to the ICU. Chest. 2006;129:954-9.

26. Martini V, Lederer AK, Laessle C, et al. Clinical characteristics and outcomes of surgical patients with intensive care unit lengths of stay of 90 days and greater. Crit Care Res Pract. $2017 ; 7$. 
27. Rordorf G, Koroshetz W, Efird JT, et al. Predictors of mortality in stroke patients admitted to an intensive care unit. Crit Care Med. 2000;28:1301-5.
28. Soliman HM, Vincent JL. Prognostic value of admission serum lactate concentrations in intensive care unit patients. Acta Clin Belg. 2010;65:176-81 